\title{
Folk Medicine and Its Second Life
}

\author{
Rosari Kingston \\ University College Cork, Ireland
}

Copyright (c) 2017 by Rosari Kingston. This text may be archived and redistributed both in electronic form and in hard copy, provided that the author and journal are properly cited and no fee is charged for access.

\begin{abstract}
Irish folk medicine is perceived to be dying, if not dead already. It lies as a parallel system to modern biomedicine and is known only through word of mouth. However, no matter what modality is practised, be it bone-setting, plant medicine, charms or rituals, there are traditional characteristics common to all as a whole. An examination of these traditional elements allows us to see how Irish folk medicine is currently practised and to ascertain whether it has reached the second life that Lauri Honko suggested. If this were the case, "the recycling of material in an environment that differs from its original context" (Honko, "The Folklore" 42) should be evident.
\end{abstract}

Key Words. Irish Folk Medicine, Tradition, Second Life, Secrecy, Provenance.

Resumen. Existe una percepción bastante extendida de que la medicina popular en Irlanda está moribunda, si es que no se considera muerta directamente. Esta práctica se presenta sin embargo como sistema paralelo al de la medicina moderna y se transmite de boca en boca. Cualquiera que sea su modalidad, ya sea colocación de huesos, medicina a base de plantas, hechizos o rituales, comparten características propias. Un análisis de estos elementos tradicionales nos permite examinar cómo se practica actualmente la medicina popular irlandesa y si ha alcanzado la segunda vida del folklore en definición de Lauri Honko. Si este es el caso, "el reciclaje del material en un medio que difiere de su contexto original" (Honko, "The Folklore" 42) debería manifestarse de forma evidente.

Palabras clave. Medicina popular irlandesa, tradición, segunda vida, discreción, procedencia.

\section{Introduction}

This article examines contemporary accounts of folk healers in Ireland. Given the widespread occurrence of folk medical practices in Ireland today, the traditional aspect of such practices may be questioned and we may wonder whether they are a modern recycling of tradition, such as that described by Lauri Honko in his influential study of the "Folklore Processes" (1991), where he distinguishes between the (traditional) "first life" and its (non-traditional) "second life". The "second Life" of folklore, Honko explains, concerns "the recycling of material in an 
environment that differs from its original context" ("The Folklore" 42). In this article, I will examine some instances of Irish folk medicine, as it is currently practised, to ascertain whether they fall into Honko's "second life" category or should rather be regarded as modern attestations of a living vernacular tradition of folk medicine.

\section{Methodology}

To answer this question, I interviewed thirteen practitioners with different healing methods in various parts of Ireland. This included healers from the south, the south-east, the west, the Midlands, as well as counties Meath, Westmeath, Leitrim, and Tyrone. This broad sweep across many of the counties of the island of Ireland is to investigate the current situation of their healing practice, as well as to establish values, norms and traditions that are common to them. Names of healers were obtained through word of mouth from patients and colleagues and initial contact was made by telephone call. The healers interviewed ranged in age from the mid-fifties to the mid-eighties. Each interview was recorded between 2012 and 2016 and lasted, on average, one to two hours. Some of the most interesting comments and information came after the recorder was turned off. This informal chat and openness "off the record" confirmed, for me, the fear of publicity and reticence that is so prevalent among the healers including those that did not mind their names being used. Some healers did not wish to be identified and, in these instances, I chose a forename as a pseudonym and did not use their real name. Where there was no objection to identity disclosure, I have used both forename and surname as well as location details. This openness reflects the position of Peter Nolan who notes that a "considerable degree of rapport is needed to gain cultural and psychological insights into how the rural Irish people construct their world and into the meanings they attribute to human behaviour" (44).

Protection of identity is also necessary as Irish healers are shy of publicity and, as Ronnie Moore notes, the "cures, curing, and healing were not casually talked about" and "information on cures and charms was not normally volunteered but ... often introduced by a family member or close friend in a personal and private context" (111). Buckley also observed that it was difficult to find a healer, and a person "is likely to be told of one by a relative, neighbour or other acquaintance" (17). Sr. Nora Smyth from Belfast, who has written about the healers she has met over the years, stated that healers have a natural reticence about their gift: "Most of the healers that I have dealt with are extremely reticent to talk about their gift" (Smyth, Personal communication). She reiterated: "Genuine healers, in my limited experience, are usually very reluctant to speak about their powers". This diffidence is almost a hallmark of the profession and unless the healer has changed his/her mode of practice, it remains a persistent trait among them. Yet, Nolan contends that because the Catholic Church, since the Second Vatican Council, has encouraged lay people to use any gifts they have in the service of the sick, it "may have made quack healers less reticent than they were to admit to having a cure" (55). Nolan further points out that in Ireland, unlike England, the term "quack" is not derogatory but simply "refers to someone not medically trained but who is regarded as having the cure for certain physical diseases or a special gift to help those in need" (45).

\section{Healing systems}

The two main types of healing systems used in the world today are biomedicine and traditional medicine. The former is the usual/common health care system in the Western world, including Ireland, which the Oxford English Dictionary defines as "the science or practice of the diagnosis, treatment, and prevention of disease (in technical use often taken to exclude surgery)". Traditional medicine includes all medical traditions other than biomedicine and may be further divided into two branches, literate and oral. China, India and Greece have 
given us the great literate traditions of Chinese, Ayurvedic and Unani medicines with their vast respective repositories of medical manuscripts and centuries of clinical expertise evident in tomes such as the Characa Samhita in Ayurveda which dates, according to the estimations, from between $100 \mathrm{BCE}$ and $200 \mathrm{CE}$. The second branch of traditional medicine covers the oral medical traditions of indigenous communities. Irish folk medicine falls under this classification. Oral medical tradition comprises two categories: on the one hand, the medical practices that are focused on the supernatural, and on the other the medical practices that employ empirical means such as using cobwebs to stop bleeding or holly to stop ringworm in cattle. Researchers in various disciplines have noted this division. The anthropologist W.S. Lyons attests to its presence in his extensive work on Native American medicine and so does the psychiatrist A. Kleinman in his exploration of the effect of culture on illness (Kleinman, Patients; "Medicine's"; Kleinman and Benson). Ó Súilleabháin alludes to this division within Irish folk medicine when he notes that the herbal medicine specialist is seen as having a lower status than the "wise" man or woman who effects a cure through ritual. He ascribes this to the "attitude of primitive man everywhere towards sickness and disease, an attitude that is completely foreign to the rational world in which we live" (58). The "primitive man" is more impressed by the "ceremonial curing of a complaint, by the recitation of an often corrupt spell or charm (ortha in Irish), as well as by complicated acts and gestures" than "the straightforward cure of an ailment by the application of a plaster" (58) or other remedy.

The worldview that informs indigenous medicine is very different to that of biomedicine and Nolan maintains that, in Irish folk medicine, it is the "cultural and ideological context which gives meaning to their practices" (46). Folk medicine is tied to local culture and environment and is based on traditional beliefs, the knowledge of which is kept alive by a few active bearers of tradition in each community (Ó Súilleabháin, Irish Folk 10). Ó Súilleabháin also sees folk medicine as "an integral part of folk culture" and posits that any enquiry into its efficacy must take the environment into which it is practised into consideration ("Foreword" viii). He is aware of the effect of the modern (European) world view, with its emphasis on reason, on its practice and does not see the "cures" and rituals that are present in Irish folk medicine as practices to be retained, as they are the cultural response of their time to illness and "completely foreign to the rational world in which we live" (Irish Folk 58).

He ascribes these practices to a large body of superstitious belief that appears strange to the modern mind but which seemed normal and rational to those who used them in the past (Ó Súilleabháin, A Handbook 304). He does admit however that "In their own day, all of these 'doctors' and many others whom I have not enumerated filled a very useful social function, although their activities would be looked upon askance in our less sympathetic days" (Irish Folk 60). Some of these social functions included, "sound advice beyond the power of others", and therapeutic efficacy through the placebo effect (Irish Folk 58; "Foreword" x). Nolan also attests to the importance of local knowledge to the healer: "The important thing about quacks is that they have an intimate knowledge of the villages they live in and of the people they live with" (45). Logan affirms that many patients will be "greatly helped by being able to tell all their worries to a sympathetic listener" (2).

Unlike Ó Súilleabháin, Moore (105) does not see folk medical practices as confined to the past: according to him, they are still an integral part of the health beliefs and health resources of the communities living in the rural towns of Ballymacross and Hunterstown in Northern Ireland that he surveyed in 1995/6. He noticed that the communities in these towns "utilised health-belief models that paradoxically straddled both formal (scientific) and lay (superstitious) accounts of health and illness with relative ease" (105). In both communities, there were healers and some of these individuals were ascribed "special mystical healing properties". There was a strong belief in both communities in "the cure" and "the charm" and 
these terms were interchangeable (111). Like Ó Súilleabháin, Moore also noticed the importance of ritual and the supernatural and remarks that "the cure" is associated with "pagan cosmological ideas of health involving magical and supernatural beliefs, and not necessarily tied to religion or religiosity per se" ("A General" 115). Wayland Hand maintains that the curing rituals present in folk medicine bring "an added measure of power and healing efficacy" but it is not easy to prove the connection of these curing rituals with ancient cultic and mythological ideas (140). This association of the cure with the supernatural also concurs with the many narratives in the Irish National Folklore Collection (NFC), where healing is associated with the spirit world. These accounts "provide an indicator of attitude to belief in fairies and healers among large sections of the rural population" (Corrigan Correll 14).

Moore (116-117) noticed in his work that health professionals, including GPs, were aware of folk healing and gave it a tacit acceptance. This acknowledgement was due in part to their belief that folk healing, especially for minor ailments, took pressure off overburdened practices and were, in the main, therapeutic. Some health care professionals also sought "the cure" for themselves or livestock and some "routinely incorporated traditional healing into their own practice" ("A General" 118). From his ethnographic research in Ballymacross and Hunterstown, Moore sees folk medicine as a means of "emphasizing ritual and culture, social bonds and neighbourliness". Belief in "the cure" was the "mortar binding a distinct and fundamental value system in these communities" (125), one which, Buckley says, resides in a cultural context that also included belief in the evil eye, banshees, ghosts and fairies (18). This pragmatically orientated world view, in relation to "the cure", may be clearly seen in Buckley's observation that for some illnesses, the patient bypasses the local doctor and goes "immediately to an unorthodox practitioner". This approach is taken where it is well known that biomedicine does not have a swift cure and includes health issues as widely varied as "skin cancer, sprains, and ringworm" ("Unofficial" 16).

It is this common fund of traditional beliefs, values and knowledge that informs folk medicine. In the following pages, some of the aspects of traditional healing, explicated and clarified by the folk healers interviewed, shall be explored. The discussion of these central elements of the contemporary healers practice shall also seek to identify whether these particular folk medicine traditions have achieved a second life distinct from their first life which ends with documentation and archival of that tradition (Honko, "The Kalevala" 185). The work of the NFC with their collection of folk medicine narratives, as well as studies such as that of Buckley, Nolan, and Moore, are instances of this documentation. The question is then: are these elements, as expounded by the healers themselves, divorced from their traditional cultural context, do they have a different modus operandi, or are they still part of a traditional community and its functionality? Each interview included questions such as: "how long are you or your family practising?"; "How did you get the cure?"; "What do you cure?"; "Will your children carry on the tradition?" The interviews were open-ended and, on analysis, the responses were much broader than the questions asked but fell generally into the following divisions: dislike of publicity, lineage, oral tradition, difference between the cure and the bottle, sense of identity, sense of service, no payment, and scope of practice. These divisions will now be explored.

\section{Elements of folk medicine}

1. Dislike of publicity: A dislike of publicity is a common trait among healers. Agnes, who has a blessing for shingles, ${ }^{1}$ acted very promptly when she heard that her cure had been mentioned on a local radio: 
... I had a friend living down in Mayo and she rang me and said that my cure had been mentioned on the local radio, the Mid West radio or one of those kinda [sic] things and I rang up the radio station straight away and said we don't advertise and I don't want my number or my name given out again ... Not that I'm offended or anything but I said that's not the way the cure works. It just has to be spread, ... and you wouldn't be advertising yourself or saying anything. But even at that time you are trying to damp it down and say ... it still spreads word of mouth ... all the time. (Interview)

Similarly, Simon ${ }^{2}$ said "People come to me on their own and I don't look for work" (Interview). Brigid ${ }^{3}$ said something very similar: "I don't say I'll do it. They have to ask. That's the way I look at it. If they bring it up and they want it. I'll do it no problem but I don't want to be saying to them I can do it" (Interview). Anne, who has a cure for shingles ${ }^{4}$ and whooping cough, said she cannot look for work or offer to use her healing ritual unless she is asked. However, if the local hospital or local nursing homes call her, she will go there to treat the patient (Interview). Nolan refers to this dislike of public exposure as part of the quacks' "unwritten code of practice" where "they never advertise their services ... They never declare openly that they have a cure, nor do they speak about those who possess other types of cure" (145).

2. Lineage / Provenance: An awareness of the lineage of their cure and that it has been in the family for centuries is another common feature. Simon said: "we can trace it back nine generations, but a person I recently spoke to said that it went back a further three generations that they could tell from their research". He was also able to relate the provenance of another healer's cure for skin cancer:

The man that he got the cure from was a ninth cousin to my father and the story is that the cancer cure were [sic] given to the girl of the family and the skin cures were given to the son of the family. There were two in the family nine or ten generations ago. (Interview)

Victor Lane, a bone-setter from Co. Cork, mentioned that the family has the gift since penal times and Dan O'Neill, a bone-setter from Co. Carlow, was aware that the gift was in the family for many centuries: "When I started, the schoolteacher down there said it was in the family for 400 years. He was a kind of historian himself" (Kingston, "A Tale" 94). The lineage is generally from parent to child or from an aunt or uncle to a niece or nephew. But, this is not always the case: in one instance, the "cure" is not passed on, as in the example of the bone-setting gift in the O'Neill family in Co. Carlow, where a member of the family will receive it after the death of the current holder. This will only happen however if the gift is perceived to be needed in the community (Kingston, "A Tale"). Kathleen Williams has a cure for jaundice ${ }^{5}$ but the cure came into this family through friendship with a man her uncle-inlaw used to visit:

The man himself was Dick Dalton who originally had this cure ... [he] was always going to him for this bottle for you and for me and for someone else; going from down here where we are, which would be about 10 miles or fifteen miles. He used to go to him all the time and at one stage he [Dick Dalton] said to him, 'look Tom I'm getting old, I'll give you the remedy'. (Interview) 
And the uncle continued to make it from then on. A sense of mystery may also accompany the transmission of the cure, as in the case of J.P. Dowd who has a charm for stopping haemorrhage. ${ }^{6}$ In this instance, he received the charm from a total stranger in the middle of a busy mart day and he has now passed it onto his son. Victor Lane received the gift of bonesetting from his father but remarked that in their family "the gift is lost in that branch of the family, where the eldest born child is a boy, but it has always been in the family where a girl is born first" (Lane 2012 Interview). Anne (Interview) received the ability to heal shingles and whooping cough because she shared the same the same initials and surname as her husband.

3. Oral tradition: All the healers interviewed, with the exception of J.P Dowd, who received the cure on a piece of card, received the cure through oral transmission. From the age of twelve, Victor Lane was actively taught by his father, whom he would have accompanied on his foraging expeditions through the fields before then. In a similar way, Sean Boylan (2012) ${ }^{7}$ and his siblings would have started weeding the herbs and helping to make the "bottle" from a very young age. Simon was about four or five when he started accompanying his father "I used to go with him picking the herbs since I was that high. I learnt to pick the right type and the right ones ... I was about four or five, I'd say" (Interview). Stephen, who has a cure for skin cancer, remembers "as a young lad I used to see it". As he got older, he helped with applying the plaster:

He [uncle] had it all done and he had me put on this [plaster]. 'That's enough' or 'that would want a little more' and after a while then sure he didn't have to tell me. He'd just look, you know. (Interview)

4. The cure: In Irish vernacular usage, the words "he has a cure" signify that the type of healing being practised belongs in the folk medical tradition. The variety of healing practices among my interviewees included charms, blessings, plant formulae, bone-setting, rituals and cupping. They were all without fail described as "a cure". Buckley in his exploration of the cure in Ulster says that the cure "is closely identified with the person who administers it" and that the healer's name is followed by the type of cure such as "he will have 'the cure of the heart or the cure of the sprain"' (20). The cure can only be administered by those who are entitled to use it and this relates to its provenance or lineage. Nolan says that "The quacks treat those who come to see them by the performance of rituals and the recitation of prayers, or by the use of herbal concoctions and secret recipes" (49). Within the generic description of someone having a cure, one of my interviewees made a distinction between a "cure" and a "bottle". The latter is understood as something you drank and was usually a plant-based formula. This was/is not always the case, as Agnes pointed out when speaking about another healer:

He does a little bottle of a cure and it's for a variety of things ... I think he can use it for pains ... but it's not a herbal bottle, it's a cure bottle. It's a water like a holy water ... and I think you have to put whatever water you don't use on yourself ... you have to put it in on a ditch you know where you can't walk on the water ... I'm not sure of the details but that's a very famous one. (Interview)

The term "a bottle" still resides within the general world of "a cure", but bone-setting does not come within this generic title but instead merits its own category, that of the same name. 
5. Sense of Identity: Each healer's sense of self is tied in very closely with their healing practice and this defines and circumscribe their life within the community, in terms of availability and being known as the person with the cure. In some instances, the community was even responsible for the healer commencing practice. Even though Simon had collected herbs with his father as a child, he only started practising in Ireland as a result of a conversation with a friend of his father's:

I was having a drink with an old friend of my father's and he said, 'what's happening about the cures'?

And I said, well he trained me how to do them but I haven't done them while I'm in Ireland but I've done them while I'm in [different] places.

[This] friend of my father said, 'don't let the cures die out. You are the only one, the only one I understand who has them, one of the family, don't let them die out, give them to somebody else'. So, I considered it and well, I'd do it myself. So, I started doing it then. (Interview)

Dan O'Neill began the practice of bone-setting after his grandfather's death, as a result of pressure from a man from Tulla:

I was the only male ... around the place, and he [grandfather] was about three weeks dead, and a fellow rang up from Tulla one evening to say the young one was after falling, and there was something wrong with her arm. So I told him about another uncle and aunt of mine.

'I don't know those people, I know you, sure you'll look after me'.

'I will', I said, 'but you're wasting your time coming out'.

$[\mathrm{He}]$ brought out the child that night, I grabbed the wrist, and I said, 'I think that the wrist is dislocated'.

'If it is, you put it back'.

I said, 'I won't. Bring her to my aunt, it's the nearest place'.

'A Neill will do it, and go and do it and don't let down the name. You're the only one left now'.

So, I said 'fair enough' ... He wouldn't leave until I tried it.

'Fair enough, if you want to chance it I'll chance it, but don't blame me if it goes wrong'.

'It won't go wrong'.

[I] caught the hand, gave it a twist and it clicked back in.

'Now can't you do it? And stay at it now'.

That was the beginning of it. (Interview)

Agnes is also aware of being known as healer: "You'd be known far and wide. If I go to a wedding, go to a funeral ... people would say, Oh, yeah I know you ... you're known because of it" (Interview). Victor Lane commenced practising as a bone-setter after a protracted period of training by his father. He inherited the gift and the community always expected that he would become a bone-setter. The career guidance teacher ignored him in school. He was told: "Your father is the bone-setter ... you'll follow him" (2012 Interview).

However, practising as a healer can also bring disruption to one's home and social life and Agnes is aware that her practise caused disruption in her children's lives:

I'd say at times they would [have] found it almost intrusive of their lives; probably in ways ... people coming to the house. Sometimes people may be chatting too much to 
them or ... they might have found it intrusive at times ... helping them with the homework or things like that you'd be called again ... there would always have been a business about the house I suppose, people calling ... it obviously doesn't take that long. (Interview)

This sense of daily disruption was also mentioned by Stephen:

... people used to come [to my uncle] every day at all hours. They could come in the morning, they could come at noon, they could come at evening time and I used to be doing a bit of farming and I'd be trying to [do] things there in the evening. People would come and go in. Then I'd have to go in, and I'd be working late at night then on the farm when everyone else be gone home. I had a wife and one small child at the time. Sundays was [sic] taken up. We could go nowhere but he [uncle] wanted to do that every day. So, I said, 'no' I didn't want to do it, because of that really, [to] throw away all my free time. (Interview)

Anne mentioned that on Christmas Day 2016 two people called for the cure for shingles and she "was not the flavour of the month" among the family waiting for dinner (Interview). Victor Lane remarked that he rarely went to dances as the Friday or Saturday clinics often finished too late to attend: "There were no appointments - the door closed at $7 \mathrm{pm}$. sharp, while anybody who was still waiting in the hallway was treated" (2012 Interview). Agnes said that her brother's family, even though he has ceased practising due to ill health, is still affected by the number of callers:

... they would have found it I think even more intrusive into their lives than my sons would have found it ... because James would have been the main person doing it at all times. They would have had people constantly coming. Because even since he has stopped ... they have had to take their phone off the register. ... People still land at their door ... even still two years later they are being inundated by people, who heard of it ten years ago, and are still coming to the house to them. (Interview)

6. Sense of service: The sense of service to the community remains strong among all healers. J.P. Dowd (Charm for haemorrhage) has his mobile phone at all times and will answer it no matter what time someone calls. Stephen changed his uncle's regime from seven days to five: "I changed it then [so] that I only done [sic] it in the evenings", whereas people would have dropped in to see his uncle at all times. He is still aware of how it intrudes on his workday:

It's a big commitment being here five evenings a week and just to be here and maybe a hay day and you hoping to make hay or something. [In] the evenings three and five cars in the yard waiting and your wife ringing to say there's five here waiting in the yard, you know. (Interview)

On asking him if there was any night he was free, he replied "No, I work the five nights." This does affect his social life because on the afternoon I called he said, "I'd love to go to the football match this evening and watch the children ... where they're playing a match at seven o'clock. I can't. I have to be here" (Interview). Similarly, Agnes finds herself very busy:

But I could be fairly inundated. Like I could come home from work and there could be five cars in the yard. Now, I don't do a specific time, an actual time because I'm 
like my mother, ... If I tied myself to seven o'clock on a Monday evening that's when I'd want to be in some place else. (Interview)

Kathleen Williams does not find much demand for her bottle now and if she is unable to meet the person she will make up the bottle and leave it somewhere for them to collect (Interview). Richard Nolan and his wife, despite being busy with farm work, will see people whenever they call and both have noticed that, sometimes, many people will call in a short period of time and then nobody will call for a few weeks. Some visits may take up to an hour as people like to talk but they consider that this is part of the responsibility of the "gift" (Interview).

7. No charge: Most healers do not charge but a donation is appreciated, although the amount of the donation is not specified. Nolan notes this lack of payment: "they never accept monetary payment" in the "unwritten code of practice" (45). Logan also mentions "that in many cases money was refused" and though it "it was customary to give a small present ... this was never large" (3). Stephen has the following to say about charging:

It was never done all along. My uncle didn't charge and his uncle didn't charge and his mother didn't charge before that and I didn't see any reason to change it. ... Well if someone wants to leave something, no problem. I had a woman who came in the other night. I done [sic] a little job for her, and she brought me four pots of jam ... Lovely, blackberry jam, I was as happy as the flowers in May. (Interview)

Similarly, Agnes says that

People leave embarrassing stuff at times. You know they will leave chocolates, they will leave jam, but they will leave money in an envelope as well whether you like it or not and they'll say that's for your husband or 'treat somebody' but you always emphasise to people there is no charge. There's no need to do anything, you can light a candle for me you can say a prayer for me, you can, whatever you want to do yourself. (Interview)

The bone-setter Victor Lane charges, but Dan O' Neill is happy with a contribution (Kingston). Sean Boylan (2012 Interview) charges and this was initiated when his father had to employ people to help with the growing, harvesting, processing and making of the "cure". Richard Nolan and his wife are vehement in refusing all donations and instead ask people to give a contribution to a charity or to say a prayer (Interview). Simon accepts donations but does not charge. The amount he receives is usually small, but a drink is frequently bought for him in the local pub. He sees this as an appreciation of his work by the local people, which is something Nolan also notes: "the quacks are held in high regard by the communities in which they live" (45). All the healers who do not charge practise part time. Sean Boylan and Victor Lane both charge but their healing practice is also their only source of income.

8. Awareness of their scope of practice: The healers are very much aware of what they could and could not do. J.P. Dowd stressed that his charm was for all haemorrhaging and not just for bleeding (Interview). Victor Lane is aware that he is losing skills, as he no longer heals fractures due to better pain management in hospitals. The precise knowledge of the splint used in fractures is no longer needed: "The splint used for healing fractures was of ash: I would be going by the diameter ... as straight as possible ... the diameter would be about 4 inches ... that branch then was cut". He explained how the inside would then be hollowed out, "and the ends bevelled back so that the skin would not be cut". He emphasised how "it had to be ash, as the ash had some healing property for the bone marrow" (Interview). 
Both Dan O'Neill and Victor Lane were remarkably well aware of the limits of their skills. Lane also pays great attention to his sense of touch: "It's a sense ... I can get the sensation through my hands and once I get that, I know there's a problem in that area, so I start looking for the problem" (2012 Interview). He will immediately recognise a serious pathology, especially in the spine, as "the skin is different". If he suspects such a problem, he will send the person to their GP with the advice that he "may have an infection that needs to be looked at". He employs this euphemism in order to avoid alarming the patient. Dan O'Neill will not fix a fracture if the bone protrudes through the skin. His definition of bonesetting captures the scope of its practice - "replacing dislocated bones" (Interview). I discussed with Simon the possibility of using different methods of preparation for his creams, but he sees no reason why he should change the way he was taught, even though an alternative method would mean he would not be dependent on the very narrow time frame which he currently has to pick and dry the herbs. Stephen is acutely aware of what he can and cannot treat: “... If I wasn't able to do it, I'd tell them that I wasn't able to do it and they'd have to go further" (Interview).

Sean Boylan on the other hand has expanded his scope of practice. He is the one healer of whom it may be said that he possibly now operates his healing "in an environment that differs from its original cultural context" (Honko, "The Folklore" 42), a point which will be discussed in more detail in the next section.

\section{The second life of folklore and folk medicine}

Honko argues that folklore in its second life very seldom reverts to its roots, namely "to the communities from which it originally came" ("The Folklore" 42) as its "first life ends with the documentation of tradition" and "it joins the queue waiting for the beginning of a "second life' - getting taken into use again, published, performed, recycled" (Honko, "The Kalevala" 185). Honko's theory revolves around the following ideas: firstly, the first life of folklore, which includes folk medicine, is imperceptible. It is not singled out as anything special. It is part of the fabric of everyday living and "is a natural part of a broader tradition system and not very easy to identify" ("The Kalevala" 185). Secondly, the tradition is discovered by strangers/outsiders and is documented: "The discoverers of folklore are usually outsiders" (184). The tradition becomes objectified through this articulation and loses its anonymity within the fabric of everyday living, even though it is still used and maintained by the people because it is useful and functional. This is important because, as Honko argues, all "folklore must be examined primarily from the perspective of the living community, and to be specific, functionally" ("The Folklore" 30). Thirdly, the practice dies out in the community as it is no longer needed, nor is it functional, and the only knowledge of it now resides in archives and documents. Finally, it is re-discovered by another generation but is now in a new format. Ó Giolláin, in describing the second life of traditional boats being used for "pleasure and racing" (3), attests to this latter theory.

Listening to the healers, it is evident that folk medicine is still in its first life and is built into the fabric of community life. It is not seen as anything special: Agnes places the blessing on the shingle lesions and then helps her children with homework. Administering the cure is seamless and almost imperceptible within the everyday chores. It is not something she has discovered, she has grown up with it; it is a part of her way of living. As already mentioned, Agnes is aware of being known as healer: "You'd be known far and wide. If I go to a wedding, go to a funeral ... people would say, Oh, yeah I know you ... you're known because of it" (Interview). Similarly, the career guidance teacher ignored Victor Lane in school and he was told: "Your father is the bone-setter ... you'll follow him" and Victor did not object. It was as normal as any other boy following in his father's footsteps (2012 
Interview). That folk medicine is part of the community world view is visible in the number of people going for a cure. Agnes and Stephen both commented on the number of people waiting for them of an evening "But I could be fairly inundated. Like I could come home from work and there could be five cars in the yard ... They would have had people constantly coming" (Agnes Interview) and "[In] the evenings three and five cars in the yard waiting and your wife ringing to say there's five here waiting in the yard" (Stephen Interview). Sean Boylan remembers the number of people calling for the "bottle" and on one particular Sunday "there was something like 63 patients waiting for his father. They had come out on the 1.55 bus from Dublin and wished to get back on the 2.45 bus" (Kingston Interview).

The desire of the community to maintain the tradition of the cure is also evident in the way the man from Tulla requested Dan O'Neill to start bone-setting because "A Neill will do it, and go and do it and don't let down the name. You're the only one left now" (Interview). This wish from the community to maintain the tradition of the cure is also noticeable in the way Simon's friend is urging him not to let the cures die: "don't let the cures die out. You are the only one, the only one I understand who has them, one of the family, don't let them die out, give them to somebody else" (Simon Interview).

Knowledge of the cures was transmitted orally to the healers. Sean Boylan was taught about the herbs from a young age, an oral teaching that became more complex as he grew older. This instruction involved not only the preparation of the herbs but also how and when to give them. Sean differs from other traditional healers in that his scope of practice is more extensive having inherited five cures through both a maternal and paternal lineage. Additionally, he received from his uncle Joe a charm for stopping bleeding and a cure for verrucas: "He cured warts, or sorry, verrucas" (Interview). Simon was out picking herbs with his father as a young lad and Stephen was observing the application of the plaster as a young boy fifty years ago. These healers are not strangers discovering knowledge that has languished in documents and archives. They are part of the healing thread that stretches back for centuries and which they continue to spin daily in their healing practice.

Logan (3) and Nolan (45) have remarked that the healer with the cure did not charge but received instead a small token of appreciation. This is evident for all the healers except Sean Boylan, Victor Lane, and Brigid. This move to being paid is an indication of the functional nature of the cure and it is worth noting that Honko realised that "Folklore cannot be bound to particular genres or individual traditional features and their preservation" ("The Folklore" 26). This functional nature is clearly seen in the reasons for which Sean Boylan's father began charging. It was to pay the employees' wages: "he had to be paid and others had to be paid and that's when they started charging for the bottles" (2011 Interview). Sean Boylan practises full time and is also involved in the growing, processing and manufacturing of his herbal formulae. As the demand for his skill and products have increased, he has had to develop good manufacturing practice (GMP) protocols from the field to the dispensary. The medicines were originally brewed in an outhouse, but, with the development of GMP, a state of the art filtration processing system was installed and a full-time chemist employed to maintain quality control. Currently, Sean Boylan is considering applying for a licence, despite the cost, from the Health Products Regulatory Authority (HPRA) that would allow him to manufacture herbal medicine for sale to third parties (Boylan 2016 Interview). This would expand the manufacturing base exponentially and would increase employment at the clinic. In this instance, it is possible to see Sean Boylan's developments in Dunboyne as the commercialisation of the cure to meet the changing demands of society. But the cure has not changed. It is the evolving demands of the society within which it functions that have changed, namely, increased demand leading to the need for staff and their salaries, goods manufacturing protocols, quality control, legislation and insurance. It is possible then to see the evolution of the cure in Dunboyne as the permanence of the tradition where "any 
permanence is in the way the community handles, interprets and values this material" (Honko, "The Folklore" 30).

Other healers have also evolved in their practices. Brigid now sees patients for an hour each day for three days whereas her father used to see them for short periods over one to two weeks: "He might have people coming to him for a week or two. He used to do it for shorter periods ... my father might only do 10-15 minutes" (Interview). She explained that this change came about because people did not have the time to come every day and often they would be coming a long distance. She noticed that reducing the number of days to three did not impact on the healing if she increased the time spent on "raising the breast bone" to the hour. Brigid also charges, but it is a modest amount (fifty Euro for three sessions). This is simply to cover her heating costs and because she received too many chocolates: "I found that in the past too, people coming with boxes of chocolates to you that you wouldn't want to be honest" (Interview). However, Brigid has not taught anyone her technique and hopes her daughter-in-law may do it in the future: "she's a nurse and she might be interested. I don't know yet, you hope that they would" (Interview). She has not shown her how to do the technique and this may be partly due to the fact that Brigid does not speak about her healing. She does not actually like people to know about it: "I don't discuss it too much with people to be honest, you know. I try not to. People can be strange and they'd nearly look at you how could you do this? You'd be surprised really" (Interview). She is busy but, like Richard Nolan from Co. Kilkenny, these busy times seem to come intermittently and she sees the tradition fading:

You see the way it goes you might have nobody for two to three months. It would be forgotten about nearly and suddenly then one would ring up. Funny when you get one, you get three or four and everyone that rings you want it very bad. They need it, you know. There was a time when I'd be getting a lot. It's fading out you can see it. (Interview)

Similarly, the distance travelled has caused Richard Nolan to change how the prayer is administered. While saying the prayer, Richard blows on each of the lesions and the person is required to return within ten days. Nowadays if a person has travelled a long-distance Richard will inform the person that they do not have to return, but that he will say the prayer for them at the allotted time (Interview). Unlike Brigid, the Nolans see a regular demand for the prayer but this may be due to Brigid living in a modern suburb and Richard Nolan living on a farm in Co. Kilkenny. The use of the mobile phone has allowed J.P. Dowd to administer his charm at all times and in 2015 he reckons he had over five thousand requests for the charm which also included calls from other countries, including England, the United States, Australia and India (Interview). The continued demand of people for the different cures shows that the healers are responding to a lived tradition in the community. Because they do not advertise, they are not telling people their cure is the answer. Instead, each of their patients is responding to a lived understanding of the nature of ill health and are expressing a wider and deeper understanding of the range of healing available. That deeper understanding includes the need for ritual, the importance of touch, and the recognition of prayer as components in maintaining health. Recovery from ill health is not limited to the physiological, but includes a world view that also embraces the emotional and spiritual as well as the physiological response. Patients are not reading about folk medicine. Someone re-discovering these aspects of Irish healing in an archive could not recognise their value, and could not replicate their effectiveness, unless they had the same worldview. These practitioners, and patients, of a newly discovered cache of healing methods would not fit seamlessly into its total therapeutic paradigm as they have not been immersed in it from birth. They would be the outsiders and would be recycling the 
material "in an environment that differs from its original context" (Honko, "The Folklore" 42).

Healers are secretive about their cures but Sean Boylan is not. He is not secretive about the formulae he inherited and imparts his understanding of these cures readily to other herbalists. He is aware of the tradition he has inherited, its place in the history of Irish medicine, and wishes to inform others of it. It may even be said that with the articulation of his knowledge it has become objectified and is no longer woven into the warp and weft of everyday living. He trains other healers in his method but conventional herbalists find this difficult to follow as it rests very much on touch, palpation, and observation (Boylan 2015 Interview). There is nothing written down and I have found it almost impossible to translate to paper the sentient and observation techniques that he uses. His experience comes from having observed his father over the decades and absorbing this knowledge until it became second nature. This echoes the experience of Stephen (skin cancer) as well as other healers such as Brigid (cupping) and Victor Lane, the bone-setter. Their knowledge becomes intuitive and the gap between the oral tradition and the scribal one remains a chasm. The first life of a tradition is essentially different to the second life because of this intuitive understanding that develops with an oral pedagogy that starts at a very young age, an experience that the rescuing of techniques and knowledge from an archive cannot match.

A second life may elude bone-setters. Victor Lane's son refused to train with him, and instead commenced training as a physical therapist because he "wanted to be legal" (2012 Interview). Victor believes that if a son or daughter does not train before the age of twenty, the gift leaves them. In this instance then, his son has not, in his father's eyes, received the gift. However, in future years his son may rescue some of his father's techniques and, if this happens, we may say that a particular form of folk medicine has gained a different life in a very changed setting. The use of the technique in this setting is a transmutation of the tradition rather than the discovery of old knowledge from archives. An example of this is the orthopaedic surgeon, Hugh Owen Thomas, who worked with his father, a bone-setter, for many years and took over this practice when his father retired. He was renowned for his skill and is deemed to be the father of orthopaedics even though the medical profession was openly hostile to his father. Building on the skill of his father in treating the skeletal problems that arise with tuberculosis he developed the Thomas splint. The use of this splint was so successful that when it was used, for femoral fractures, in the first world war it reduced the mortality rate from $80 \%$ to $20 \%$ (Birkenhead). Likewise, there is no guarantee that the gift which has appeared in the O'Neill family over the generations will appear again among the next generation when the current holder, Dan O'Neill, dies.

Agnes does not see either of her sons practising and Simon has unfortunately not passed on the formulae to his son. This is due to fear of litigation and the failure to engage with twentieth-century developments in health care. Stephen hopes to train his son but has not done so yet and his son is in his thirties. Even teaching him now is a far cry from the long training he undertook as a child with his uncle and may, as a consequence, lead to a diminishment of the diagnostic knowledge. This lessening may occur because the healing tradition is an oral tradition with the teaching commencing at a very young age. Being taught at twenty-five or thirty is not the same as being taught at three, especially if the main education, that is received in other areas, is scribal over a period of thirteen years. Victor Lane verbalised this problem when he said that the gift leaves you if you do not practise before the age of twenty (2012 Interview). It may then not be a case of being confined to archives but rather a withering of the vine due to the failure to realise the importance of this oral pedagogy in the transmission of the cure. If the eye has not learnt when to apply the poultice, or the hand has not become sufficiently sensitive to the subtlety of the underlying tissue, then the effectiveness of the cure within the community dies. Documenting this tradition and even 
rescuing it from an archive will only give it a second life very different from its first manifestation, unless this early transmission of knowledge is recognised as crucial to its identity.

\section{Conclusion}

Irish folk medicine is currently in a vibrant position and is still in its first life. It has been documented and this research may well lie in the archives to be analysed at a future date. But it is also at a crossroads. Unless the communities in which it operates still see the need for it, the tradition will die. This disconnection in the continuity of the tradition may be due to changes in education and to the general perception that biomedicine is the only medical paradigm. It is also due to the failure of healers to realise the significance and unique nature of the oral transmission of their knowledge. Sean Boylan is actively engaged with modernising his area of expertise but his children have not had the extensive oral training that he experienced from a young age. The knowledge of practitioners with other plant-based formulae may also be lost due to the difficulties faced in passing on the comprehensive but subtle diagnostic techniques, the plant knowledge, and the pharmacy to the next generation who are not immersed in an oral pedagogy and who perceive themselves as belonging to a more litigious society (J. O'Neill Interview). The continuity of the rituals and charms is more secure in that the current practitioners have passed, or intend to pass it on. Any threat to this aspect of folk medicine may come from a secular world view and a disengagement with the "pagan cosmological ideas of health involving magical and supernatural beliefs" (Moore 115) that informs the uptake of traditional medicine, although this does seem to have happened to date.

Irish folk medicine has thus not achieved a second life, in terms of "the recycling of material in an environment that differs from its original context" (Honko, "The Folklore" 42). Sean Boylan's clinic at Dunboyne is an evolution rather than a transmutation. All the other healers are practising in the traditional manner and the wide variation in the age of their clientèle indicates a healing paradigm that is both vibrant and relevant in the community.

\section{Notes}

${ }^{1}$ Agnes performs a blessing for shingles where she touches the lesions in three places, three times and says a short blessing each time she touches a lesion. The person seeking the blessing has to return three times but not necessarily on three consecutive days.

${ }^{2}$ Simon makes a cream for psoriasis, ringworm and eczema. This is a plant-based formula which he inherited from his father. The plants are wild-crafted in May or June depending on the weather.

${ }^{3}$ Brigid learnt the technique of "raising the breast bone" (sternum) from her father. It is a form of cupping. Cupping involves the placing of a glass/cup on the skin for a few minutes to create suction. This action influences the underlying deep tissue.

${ }^{4}$ Anne's cure for shingles involves touching the lesions in two places only, the first one and the last one on the nerve. She also places her thumb in the base of the skull, a position she calls "the holy water font", and makes the sign of the cross there. A person returns three times for the blessing.

${ }^{5}$ This cure is a recipe that involves Guinness and chalk. It is extremely difficult to take and there is no set ritual associated with it.

${ }^{6}$ This charm is similar to other charms for stopping bleeding, "Jesus was born in Bethlehem, baptised in the river Jordan..." (Boylan 2012 Interview).

${ }^{7}$ Sean inherited four plant-based formulae from his father. These were for asthma, tuberculosis, dropsy and arthritis. He inherited a plant-based formula for burns, a cream for external application, from his mother and a charm for stopping bleeding from his uncle Joe. This charm is similar to that of J. P. Dowd. 


\section{Works Cited}

Birkenhead, Lord Cohen of. "Liverpool's Contributions to Medicine". British Medical Journal. (April 10, 1965): 945.

Buckley, Anthony D. "Unofficial Healing in Ulster". Ulster Folklife 26 (1980): 15-34.

Corrigan Correll, Timothy. "Believers, Sceptics, and Charlatans: Evidential Rhetoric, the Fairies, and Fairy Healers in Irish Oral Narrative and Belief". Folklore 116 (April 2005): 1-18.

Hand, Wayland Debs and Wayland B. Hand. "Folk Curing: The Magical Component". Béaloideas 39. 41 (1971-1973): 140-156.

Honko, Lauri. "The Kalevala: The Processual View". Religion, Myth and Folklore in the World's Epics. Ed. Lauri Honko. Berlin, New York: Mouton de Gruyter, 1990. 181230.

. "The Folklore Process". Folklore Fellows Summer School Programme. Turku: FFSS, 1991. 25-47.

Kingston, Rosari. “A Tale of Two Bone-setters”. Béascna 8 (2013): 89-102.

Kleinman, Arthur. "Medicine's Symbolic Reality”. Inquiry 16 (1973): 206-213.

- Patients and Healers in the Context of Culture. Berkeley: California University Press, 1980.

Kleinman, Arthur, and Peter Benson. 2006. "Anthropology in the Clinic: The Problem of Cultural Competency and How to Fix It". PLoS Med. 3. 10 (2006): 1673-1676.

Logan, Patrick. Irish Country Cures. Belfast: Appletree Press, 1981.

Lyons, William S. Spirit Talkers: North American Indian Medicine Powers: Prayer Efficacy Publishing, 2012.

Moore, Ronnie. “A General Practice, A Country Practice: The Cure, the Charm and Informal Healing in Northern Ireland". Folk Healing and Health Care Practices in Britain and Ireland. Eds. Ronnie Moore and Stuart McClean. New York. Oxford: Berghahn Books, 2010. 104-129.

Nolan, Peter W. "Folk Medicine in Rural Ireland". Folk Life Studies 27 (1989): 44-56.

Ó Giolláin, Diarmuid. Locating Irish Folklore. Tradition, Modernity, Identity. Cork: Cork University Press, 2000.

Ó Súilleabháin, Seán. A Handbook of Irish Folklore. London: Herbert Jenkins, 1942.

. Irish Folk Custom and Belief. Vol. XV. Dublin: Three Candles, 1967.
. "Foreword". Irish Country Cures. Ed. Patrick Logan. Dublin: Appletree Press, 1981. vii-xi.

OED. Definition of medicine. In Oxford English Dictionary. 28 August 2017. https://en.oxforddictionaries.com/definition/medicine.

Smyth, Nora. Going for the Cure. Monaghan: R\&S Printers, 2002.

\section{Unpublished Primary Sources}

Agnes. Blessing for shingles. Interviewed by R. Kingston. August 2016.

Anne. Cure for shingles and whooping cough. Interviewed by R. Kingston. August 2016.

Boylan, Sean. Transmission of healing. Interviewed by R. Kingston. Dunboyne, Co. Meath. 2011, 2012, 2013, 2014, 2015, 2016.

Brigid. Raising the breast bone. Interviewed by R. Kingston. August 2016.

Dowd, J.P. Charm for Haemorrhage. Interviewed by R. Kingston. Carrick on Shannon. August 2016. 
Kingston, R. Field note recording 159. August 2011.

Lane, V. Bonesetting. Interviewed by R. Kingston. Newmarket, Co. Cork. 2011, 2012, 2017.

Nolan, R. Prayer for shingles. Interviewed by R. Kingston. Co. Kilkenny. November 2016.

O'Neill, Dan. Bonesetting. Interviewed by R. Kingston. Myshall, Co. Carlow. November 2012.

O'Neill, James. Informal communication. Moyshall, Co. Carlow. November 2016.

Simon. Cure for psoriasis. Interviewed by R. Kingston. August 2016.

Smyth, Sr. Nora. Reticence. Personal communication. May 23 $3^{\text {rd }}$ May $30^{\text {th }} 2016$.

Stephen. Skin cancer. Interviewed by R. Kingston. August 2016.

Williams, K. Folk remedies. Interviewed by R. Kingston. Co. Waterford. 2012.

Received: 10 February 2017 Revised version accepted: 9 June 2017

Rosari Kingston is a doctoral researcher in Roinn an Bhéaloideas/The Department of Folklore and Ethnography, University College, Cork. Her area of research is the Irish healing tradition as it is currently practised. Her work has been published in Beascna 2017 ("The Evil Eye and Biomedicine"), 2013 ("A Tale of Two Bone-setters: An Examination of the Bonesetting Tradition in Ireland"), 2011 ("Selected Herbs and their Uses in the National Folklore Schools Collection (NFCS), Co. Clare: A Case Study"). She also practises as a medical herbalist in her own private clinic in Skibbereen, Co. Cork, and in an integrated GP clinic in Clonakilty.

rkingston.kingston@gmail.com 